УдК 338.33

Ye. Bobuslavskiy,

PhD in Economics, Associate Professor, Professor of the Department

of Economic Theory, Statistics and Forecasting, Kharkov

ORCID ID: 0000-0003-2308-3606

National University of Economics of Simon Kuznets

M. Bobro,

student, Kharkov National University of Economics of Simon Kuznets

ORCID ID: 0000-0003-2671-3116

DOI: $10.32702 / 2306-6814.2019 .12 .66$

\title{
THE NEW APPROACH TO ASSESSING THE SYNERGISTIC EFFECT OF DIVERSIFICATION
}

\author{
Є. І. Богуславський, \\ к. е. н., професор, професор кафедри економічної теорії, статистики та прогнозування, Харківський \\ національний економічний університет імені Семена Кузнеця, м. Харків \\ М. К. Бобро, \\ студентка, Харківський національний економічний університет ім. Семена Кузнеця, м. Харків
}

\author{
НОВИЙ ПІАХІААО ОЦІНКИ СИНЕРГЕТИЧНОГО ЕФЕКТУ ПРИ ПРОВЕАЕННІ \\ АИВЕРСИФІКАЦІї
}

The article discusses various examples of the diversification of enterprises both by expanding production through the creation of new production lines, and through the mergers and acquisitions of ready-made enterprises. Suggested that the most successful is diversification, aimed to the production of goods that complement each other. It is in the production of complimentary goods that the occurrence of a synergistic effect is most likely. Moreover, in determining the complementarity, it becomes possible to determine the trend of the company's further development and changes in the volume of its revenue. The article also presents and describes all the most common methods for assessing the feasibility of a decision on diversification and points to their advantages and disadvantages. Analyzed various criteria for assessing the feasibility of a diversification, and proposed complementarity of goods, determined using the coefficient of elasticity of demand, as the main criterion for deciding whether to complete merger or acquisition. It's proved that in addition to assessing the feasibility of diversification, it is also necessary to have a tool that will allow to assess the amount of synergistic effect to which it will lead. None of the existing methods provides such an opportunity. It is proposed to use for this the complementarity multiplier, which will make it possible to predict the change in demand for the company's products after diversification, and therefore to evaluate the future synergistic effect. The article also presents the formula of the complementarity multiplier, which allows to predict the trend of change in income after such transactions. By the example of real companies, it has been proved that diversification, which allows to achieve a synergistic effect, leads to an increase in revenue. Article also presents the idea that insists on the fact that the return on investment is most likely when a synergistic effect occurs, which will be able to cover the costs by increasing revenues. That is, when assessing the feasibility of diversification, we should talk about the assessment of the synergistic effect to which it will lead.

У статті розглядаються різні приклади диверсифікації підприємств як за рахунок розширення виробництва шляхом створення нових виробничих ліній, так і шляхом злиття і поглинання 
готових підприємств. Запропоновано, що найбільш успішною є диверсифікація, спрямована на виробництво товарів, що доповнюють один одного. Саме у виробництві компліментарних товарів найбільш імовірним є виникнення синергетичного ефекту. Більше того, під час визначення взаємодоповнюваності стає можливим визначити тенденцію подальшого розвитку компанії та зміни обсягу її доходів. У статті також представлені та описані всі найбільш поширені методи оцінки доцільності прийняття рішення про диверсифікацію та вказуються на їх переваги та недоліки. Проаналізовано різні критерії оцінки доцільності диверсифікації, а також запропонована компліментарність товарів, визначена з використанням коефіцієнта еластичності попиту, як основний критерій прийняття рішення про завершення об'єднання або придбання. Доведено, що на додаток до оцінки доцільності диверсифікації, необхідно також мати інструмент, який дозволить оцінити кількість синергетичного ефекту, до якого він приведе. Доведено, що жоден з існуючих методів не дає такої можливості. Для цього пропонується використати мультиплікатор компліментарності, що дозволить прогнозувати зміну попиту на продукцію компанії після диверсифікації, а отже, оцінити майбутній синергетичний ефект. Устатті також представлено формулу мультиплікатора компліментарності, яка дозволяє прогнозувати тенденцію зміни доходу після таких операцій. На прикладі реальних компаній доведено, що диверсифікація, яка дозволяє досягти синергетичного ефекту, призводить до збільшення виручки. Стаття також представляє ідею, яка наполягає на тому, що рентабельність інвестицій, насамперед, відбудеться при синергетичному ефекті, який зможе покрити витрати за рахунок збільшення доходів. Тобто у разі оцінювання доцільності диверсифікації слід говорити про оцінку синергетичного ефекту, до якого він приведе.

Key words: complementarity multiplier, synergistic effect, goods complementarity, diversification, mergers and acquisitions, forecasting the trend of income change.

Ключові слова: мультиплікатор компліментарності, синергетичний ефект, компліментарність товаріВ, диВерсифікація, злиття і поглинання, прогнозування тенденції зміни доходу.

\section{STATEMENT OF A PROBLEM}

In the current conditions of enterprises' development, mergers and acquisitions of companies are quite frequent phenomena. Through such deals, firms are trying to solve various kinds of problems, such as, for example, obtaining new opportunities for further development - entering new markets, attracting new customers, etc. However, the main objective of the merger or acquisition is to achieve a synergistic effect.

According tol. Ansoff, in a long-term period, in tense situations and (or) at the moments of a recession in the conjuncture, synergistic firms turn out to be more persistent and show better performance than conglomerates. [1, p. 54] That is, the synergistic effect allows not only to increase the amount of income, but also to increase the resistance of the company to various negative factors of the macroenvironment.

As you know, one of the tools for the development of an enterprise is vertical diversification, which, in turn, can be implemented by various methods. The first one is the launch of a new production line in the enterprise; the second is the acquisition by the enterprise. Both of these methods are associated with large economic, intellectual and labor costs, which, in turn, can lead to losses. According to Kotler, $70 \%$ of diversifications are unsuccessful [2, p. 174]. That is, before implementing a diversification strategy, the firm's management must be confident that it justifies its value.

According to the authors, the main criterion for the selection of a diversification strategy should be the complementarity of goods, in the case of the addition of already existing goods with compliments, a synergistic effect is achieved, which, as has been said earlier, is the main goal of any diversification.

\section{ANALYSIS OF THE LATEST \\ INVESTIGATIONS AND PUBLICATIONS}

The use of the diversification process to achieve a synergistic effect has been repeatedly analyzed by such scientists as I. Ansoff [1], F. Kotler [2], A. Thompson, A. Strickland [3], etc. But they considered those cases where the goal of diversification there was an expansion of the product range and an increase in sales. However, in their works they did not give clear criteria for assessing the feasibility of the diversification process, but only analyzed the state of companies before and after transformations.

\section{TASK DEFINITION}

The purpose of this article is to determine the criteria for the expediency of diversification through the expansion of production or the acquisition of existing enterprises to 
achieve a synergistic effect; description of the diversification process on the example of real companies operating in various industries.

The novelty of the study lies in proposing a fundamentally new approach to determining the effectiveness of diversification with the help of a modified coefficient of demand elasticity, as well as in using the complementarity multiplier to determine the nature of the synergistic effect.

\section{STATEMENT OF THE MAIN MATERIAL}

As is known, the goal of any company is to strengthen indicators and stable growth. This goal can be achieved in various ways, such as minimizing production costs, modernizing the production process, conducting effective marketing campaigns, etc. However, the main way to increase revenue is to expand production, both by increasing the quantity of goods produced and by diversifying the range.

As mentioned earlier, diversification can be realized through the opening of a new production line, or through a merger or acquisition of a company that already produces the necessary goods. Each of these approaches has its advantages. So, when opening a new line, the management of the enterprise has the ability to manage all processes independently, and this allows to handle the control over the quality of products. At the same time, in case of buying a ready-made business, the company receives a number of advantages: streamlined production of products for which market demand has already been formed, acquired technologies help to save time on developing and optimizing production processes.

But, no matter which of the above strategies the company chooses, the management is faced to the question of assessing the feasibility of diversifying into one or another industry in order to minimize the risk of losses. It should be noted here that the return on investment is most likely when a synergistic effect occurs, which will be able to cover the costs by increasing revenues. That is, when assessing the feasibility of diversification, we should talk about the assessment of the synergistic effect to which it will lead. According to A. Thompson, most companies prefer expansion to related industries, since it provides increased productivity due to synergistic effect [3, c. 73].

There are various methods for assessing the synergistic effect, namely:

1. The overall effect of the implementation of the diversification strategy (it also includes the synergistic effect). It is calculated by the formula:

$$
\begin{aligned}
& E_{\text {загd }}=\sum_{t=1}^{T_{d}} \frac{\left[\left(\Delta \Lambda_{d t}+K_{d t}+A_{d t}\right)-\left(B_{d t}+\Pi_{d t}+5 B_{d t}\right)\right] P_{t}}{(1+r)^{t}}- \\
& -\sum_{t=1}^{T_{d}} \frac{\Pi K_{d t}}{(1+r)^{t}}+\sum_{t=1}^{T_{d}} \frac{E B_{d t}}{(1+r)^{t}}
\end{aligned}
$$

where:

$\Delta Д_{d t}$ - is the increase in revenue (revenue) from the implementation of the diversification strategy obtained in the $\mathrm{t}$-th year by expanding the scale of production, $\mathrm{UAH}$.

$T_{d}$ - the total period of the implementation of the diversification strategy (action of the diversification factor), years;

$K_{d t}$ - bank loan in the $\mathrm{t}$-th year, required for diversification, $\mathrm{UAH}$;

$A_{d t}-$ annual depreciation of $\mathrm{t}$-th year, due to the installation of new equipment, which is necessary for diversification, $\mathrm{UAH}$;

$B_{d t}$ - current expenses of the $\mathrm{t}$-th year for the manufacture of additional products as a result of diversification, $\mathrm{UAH}$; $\mathrm{UAH}$

$\Pi_{d t}-$ tax on additional income from diversification,

$5 B_{d t}$ - payment in the $\mathrm{t}$-th year of bank interest on the loan that was required to implement the diversification strategy, UAH;

$r-$ is the discount rate taking into account probable inflation, $\%$;

$\mathrm{UAH}$

$\Pi K_{d t}-$ amount of loan repayment in the $\mathrm{t}$-th year,

$P_{t}-$ the probability of selling new products in the event of diversification (the probability of obtaining planned income from the implementation of the diversification strategy);

$E B_{d t}$ - savings in operating costs, arising from reducing the share of fixed costs, since the manufacture of new products may be carried out in the same workshops, on the same equipment, stored in the same warehouses and serviced by the same personnel, and the products manufactured earlier, thousand UAH [4].

2. The method of discounting cash flows. It is based on the concept of the present value of the future cash flow of the enterprise, estimated in the context of individual periods [5].

According to the DCF method, the company's value is determined by the formula:

$$
V=E+D=\sum_{i=1}^{\infty} \frac{F C F_{i}}{(1+r)^{i}}
$$

where

$\mathrm{V}$ (Value) - assessment of the current value of the company;

E (Equity) - assessment of the current market value of the share capital of the company;

$\mathrm{D}$ (Debt) - short-term and long-term debt;

$\mathrm{i}$ - the number of the year;

FCF (Free Cash Flow) - free cash flow of the company in the $\mathrm{i}$-th year;

$r$ - the discount rate [6].

According to DCF, the fair value of a company is equal to the sum of all the funds that this company generates over the entire period of its existence.

Discount formula:

$$
N P V=\sum_{i=1}^{n} \frac{C F_{i}}{(1+q)^{i}}
$$

where

$q$ - the discount rate;

CF - the company's cash flow in the i-th year [7].

These methods are the most popular and of ten used by financial analysts to assess the feasibility of investing in a particular project. However, none of them gives an answer to the question of whether diversification will lead to a synergistic effect and to an increase in revenue. 


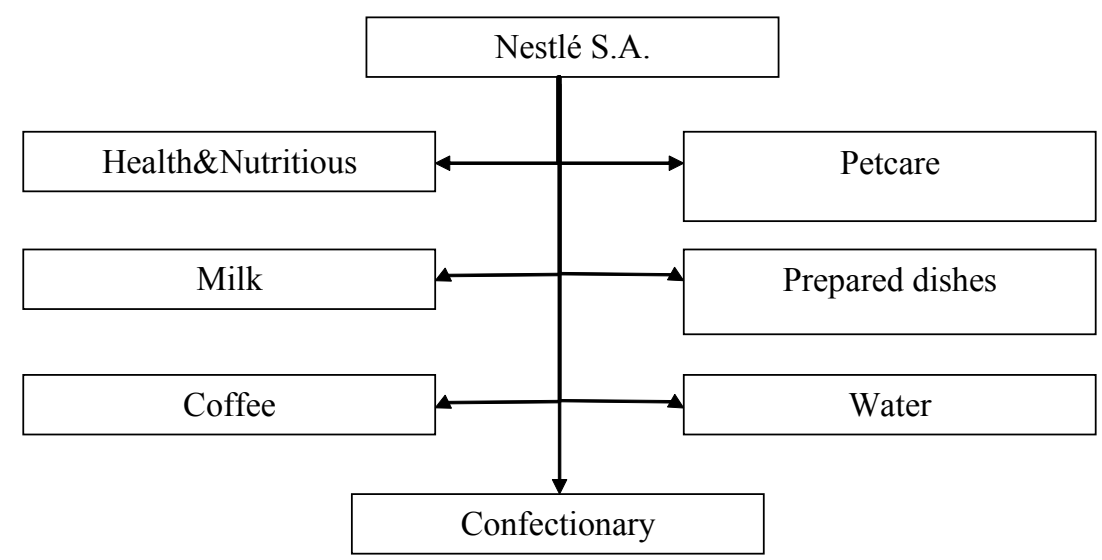

Picture 1. Structure of Nestle S.A. [11]

It should also be noted that in both methods the main role is played by the time factor, which determines the further result of the calculations. Such an approach distorts the actual situation, since it is impossible to determine the moment of the appearance of a synergistic effect, and the possibility of its occurrence in general. This means that none of these methods can determine the trend of events after diversification.

It can be concluded that all this time without attention remained one factor that, in fact, determines the further success or failure of diversification, since it is who predicts the emergence or absence of synergistic effect in the future, namely, according to the authors complementarity of goods.

The essence of evaluating the complementarity or noncomplementarity of products is that before making a decision to open a production line for new products, it should be determined which of the existing products for new products are in relation to each other complimentary goods, substitute products or independent goods.

However, in addition to assessing the feasibility of diversification, it is also necessary to have a tool that will allow to assess the amount of synergistic effect to which it will lead. None of the above methods provides such an opportunity. We propose to use for this the complementarity multiplier, which will make it possible to predict the change in demand for the company's products after diversification, and therefore to evaluate the future synergistic effect. For complementary goods, it gets a value higher than one, for independent goods - equal to one, for substitutes - from one to zero. This can be done (with some approximation) as follows:
if Exy $<0$, then $M_{\kappa}=1-E$
if Exy $>0$, then $M_{K}=1 /(1+E)$
if Exy $=0$, then $M_{K}=1$

Thus, in the case of a merger of enterprises, it is possible to carry out a preliminary calculation of the increase in demand for these goods by multiplying the existing level of demand and complementarity multiplier [8].

In the absence of the necessary data for calculations, it is not possible to verify the accuracy of this hypothesis, since it is necessary to have data on the volume of demand for goods, and these data can only be contained in the company's internal statistics.
According to the authors, the most successful is diversification, aimed to the production of goods that complement each other. It is in the production of complimentary goods that the occurrence of a synergistic effect is most likely. Moreover, in determining the complementarity, it becomes possible to determine the trend of the company's further development and changes in the volume of its revenue. But it should also be noted that the emergence of a synergistic effect is also influenced by other factors, both objective (financial crises, weather conditions, etc.) and subjective factors (management model of the board of directors, executive discipline, etc.).

Such an assessment makes it possible not only to determine the expediency or inexpediency of diversification with high accuracy, but also it is rather simple to perform, since all calculations are based on the formula of the coefficient of cross elasticity of goods $X$, $\mathrm{Y:}$

$E_{X Y}=\frac{\Delta Q_{X}}{Q_{X}} \div \frac{\Delta P_{Y}}{P_{Y}}$

where - the volume of demand for product $X$;

$P_{Y}$ - the price of goods $\mathrm{Y}$ [9].

Since it is almost impossible to estimate the volume of demand for product $X$ in physical units, it is expedient to express it in the cost of products sold by the company. At the same time, if diversification occurs in a firm with a wide range of goods, it is impossible to distinguish the average price, since this will distort the overall picture, therefore, instead of the price of product $Y$, it is advisable to use the company's revenue, since it is in the revenue that the price of the product is laid.

Thus, the modified formula of the coefficient of cross elasticity of goods $\mathrm{X}, \mathrm{Y}$ will have the following form:

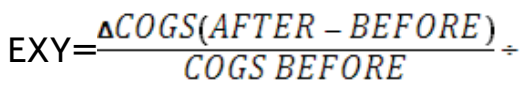

$\div \frac{\triangle \text { Sales }(\text { BEFORE }- \text { AFTER })}{\text { Sales BEFORE }}$

where COGS - cost of goods sold;

BEFORE - before diversification;

AFTER - after diversification.

The results of the calculations are treated the same way as when using the usual coefficient of cross elasticity of goods: 


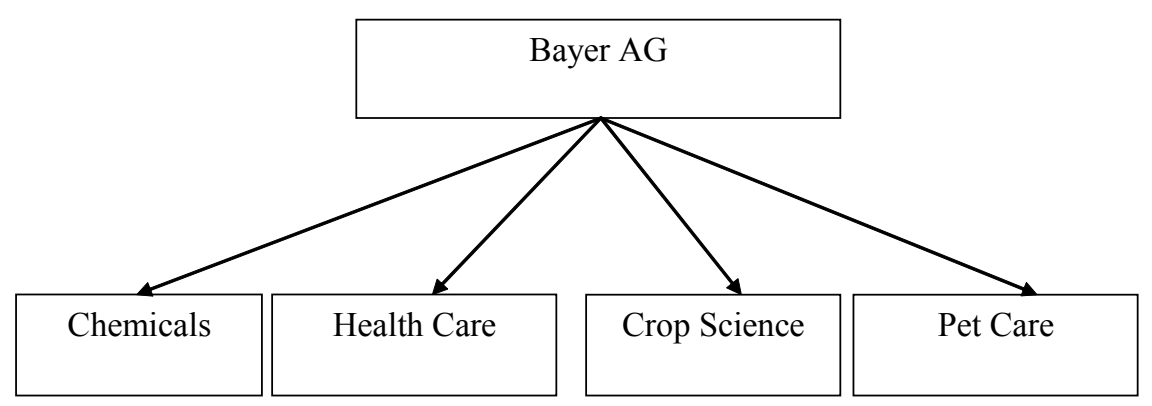

Picture 2. Bayer AG's structure

When Exy $<0$, the goods are complementary;

When Exy $>0$ - goods substitutes;

When Exy $=0$ - the goods are independent.

To confirm this theory, it is necessary to consider the statements of some companies that conducted mergers and acquisitions. It should also be noted that the companies selected for the study satisfy the following requirements:

1. Carried out mergers and acquisitions to achieve various strategic objectives (to increase production, enter new markets, expand the range of products, etc.).

2. Carry out activity in different spheres (this requirement is necessary in order to exclude the possibility of specialization of this theory and make sure that it works in various industries).

The first company selected for analysis is Nestle S.A.

Nestle S.A. is a Swiss transnational corporation, the world's largest food producer [10]. The main office of the company is located in the Swiss city of Vevey.

Nestle produces coffee, mineral water, chocolate, ice cream, broths, dairy products, baby food, pet food, pharmaceuticals and cosmetics. The main trademarks are KitKat, Maggi, Nescafe, Nesquik, Nestea. The main market for products is the United States, they account for a little less than a third of the company's turnover.

The structure of industries is shown in Pic. 1.

In the absence of the necessary reporting, it is impossible to track how the opening of new production lines affected the volume of the company's total revenue. However, the analysis can be carried out based on the effect of the 2010 transaction - the takeover of Kraft Foods' company [12], which specializes in the production of frozen pizza (i.e., the transaction occurred to expand the fast food industry). It can be assumed that pizza is a compliment to chocolate products, which, like fast food, are popular among children and used in organizing holidays, etc.

According to the formula of the modified coefficient of cross elasticity of demand, which was presented above, calculations are made according to data from the official financial statements of the company [13]:

$$
\mathrm{E}_{\mathrm{XY}}=\frac{\text { COGS2010-COGS2009 }}{\text { COGS2009 }} \div \frac{\text { Sales } 2009-\text { Sales } 2010}{\text { Sales } 2009}=
$$$$
\frac{45849-45208}{45208} \div \frac{107618-109722}{107618}=(-0,7194) \text {. }
$$

Since $E_{X Y}<0$, the products that were previously produced by Nestle S.A. and a new product - frozen pizza, is complementary, therefore, the acquisition of this production will lead to a synergistic effect.

If we analyze the report on the profitability of the company for 2011 [13], then we may notice a decrease in the amount of revenue by $10.0769 \%$, but already in 2012 , the revenue increased by $10,2149 \%$, which compensated for the fall of 2011. In 2013, revenue growth amounted to $2,7162 \%$, which indicates a positive trend. It should also be noted that in the absence of data, it is difficult to calculate the share of revenue from the acquired company in the total volume. That is, it is difficult to determine how much exactly this company brought.

However, based on calculations, we can confidently assert that the acquisition of the production of complementary goods had a positive impact on the company's development trend, and, subsequently, led to the emergence of a synergistic effect.

The second company that also has a positive synergistic effect from acquisitions is the multinational pharmaceutical company Bayer AG.

Bayer AG is a German chemical and pharmaceutical company founded in Barmen (currently part of Wuppertal, Germany) in 1863. Its headquarters is located in Leverkusen, North Rhine-Westphalia (Germany) [14].

Concern "Bayer" represents over 350 companies in all countries of the world. The number of staff $-106,2$ thousand employees.

In order to separate operational and strategic management, Bayer AG was transformed into a holding company in 2003. The divisions that make up the core of the group have been transformed into limited liability companies controlled by Bayer AG. These include:

- Bayer CropScience AG;

- Bayer HealthCare AG;

- Bayer MaterialScience AG;

- Bayer Chemicals AG.

There are also three service companies: Bayer Technology Services GmbH, Bayer Business Services $\mathrm{GmbH}$ and Bayer Industry Services $\mathrm{GmbH} \& \mathrm{Co} . \mathrm{OHG}$ [15].

Bayer carries out its activities in four areas, as shown in Pic. 2.

Further it will be reviewed 5 transactions on the takeover of enterprises in the period from 2000 to 2011 , and their impact on the company's development trends will be analyzed.

1. In 2000, Bayer acquired the polyol business of the Lyondell Chemical Company in the United States [16]. After that, Bayer becomes the world's largest producer of polyurethane raw materials.

As is known, due to the many advantages (durability, environmental friendliness, elasticity, strength, low cost, etc.), polyurethane is used for the manufacture of polyurethane products for various purposes. It is used in the manufacture of footwear, rollers, mattresses, 
technical gaskets, sleeves, cuffs, rings and other sealing parts. It is often used as a heater, protective coating, insulator and for other purposes. Thus, it can be assumed that this product can be used in any of the activities of the company, and, therefore, complimentary to it.

$$
\mathrm{E}_{\mathrm{XY}}=\frac{\text { COGS } 2000-\text { COGS } 1999}{\text { COGS1999 }} \div \frac{\text { Sales } 1999-\text { Sales } 2000}{\text { Sales } 1999}=
$$$$
\frac{15949-13217}{15949} \div \frac{27320-30971}{27320}=(-1,54) \text {. }
$$

$E_{x y}<0$, which means that the polyol business is complementary to the core activities of Bayer.

Analyzing changes in revenue in 2001, 2002 and 2003 , we can trace the downward trend - in 2001 , the growth rate was $97.75 \%$, in $2002-97.85 \%$, and in $2003-96.43 \%$ [16]. This trend is negative, as over three years, revenue increased by an average of $2.66 \%$ annually. However, it should be noted that in 2000 the whole world was in a state of deep financial crisis in the field of IT-technologies, which led to the bankruptcy of many corporations, while Bayer revenue fell only by $2.66 \%$.

This can serve as direct evidence that, as I. Ansoff suggested, synergistic companies are more resistant and resistant to exogenous negative influence.

2. In 2001, the company acquired Aventis CropScience, an enterprise for the production of various vegetable fertilizers. After that, Bayer became the world leader in the field of plant protection [16].

$$
\begin{gathered}
\mathrm{E}_{\mathrm{XY}}=\frac{\text { COGS } 2001-\text { COGS2000 }}{\text { COGS2000 }} \div \frac{\text { Sales } 2000-\text { Sales } 2001}{\text { Sales } 2000}= \\
\frac{16747-15494}{15494} \div \frac{30971-30275}{30971}=2,22 .
\end{gathered}
$$

The value $E_{X Y}>0$ indicates that the acquired company is engaged in products that do not complement the existing one, but replace it, that is, it is not a compliment, but a substitute.

Acquisition of the production of substitute goods always negatively affects sales of an existing product range and causes a decrease in demand for it. This follows from the financial statements, after analyzing which it is clear that in 2002 revenues decreased by $2.15 \%$, and in 2003 - by $3.57 \%$. But it should be noted that in the analyzed period of time there were still consequences of the financial crisis, which also had a negative impact on the market.

However, in describing this deal, we cannot speak only about its negative impact on the company's activities. Moreover, analyzing the further actions of the company's management, it can be concluded that this acquisition was a deliberate strategic step that brought the company to the position of a leader in the field of plant protection. On the basis of the acquired enterprise, a separate division was subsequently formed, specializing in the development of plant protection products.

3. In 2005, there was a takeover of Roche consumer health business - a company that developed over-thecounter medicines [16].

Such products may be complementary to already existing products of the pharmaceutical line, since if the products of the pharmaceutical line are used during the acute stage of the disease, over-the-counter medicines are used for the prevention of diseases.

$$
\mathrm{E}_{\mathrm{XY}}=\frac{\text { COGS2005 - COGS2004 }}{\text { COGS2004 }} \div \frac{\text { Sales } 2004-\text { Sales } 2005}{\text { Sales } 2004}=
$$
$\frac{15027-12421}{12421} \div \frac{23278-27383}{23278}=(-1,19)$.

$E_{X Y}<0$, therefore the goods of the absorbed enterprise are complementary to the already existing goods.

After analyzing the change in revenue over the next three years, you can see a positive trend, namely - in 2006 the increase was $5.74 \%$, in 2007 - $11.84 \%$, and in $2008-$ $1.65 \%$. As we see the most obvious result of the takeover was in 2007. Thus, it can be concluded that a synergistic effect has been achieved.

4. Acquisition of Athenix Corp. in 2009 - a private biotechnology company specializing in research in the field of plant protection and fertilizer development [17]. The activity of this company allows us to develop and improve plant protection products, which means that we can assume the existence of complementarity between this research activity and the products existing in this industry.

$$
\mathrm{E}_{\mathrm{XY}}=\frac{\text { COGS2009-COGS2008 }}{\text { COGS2008 }} \div \frac{\text { Sales } 2008-\text { Sales } 2009}{\text { Sales } 2008}=
$$
$\frac{15135-16456}{16456} \div \frac{32918-31168}{32918}=(-1,51)$.

$\mathrm{E}_{\mathrm{XY}}<0$, which means the products are complementary and the acquisition of this enterprise will allow the company to achieve a positive synergistic effect. This is proved by an analysis of the change in revenue over the next three years. In 2010, revenue growth was $12.58 \%$, in 2011 $4.1 \%$ and in $2012-8.79 \%$ [17].

5. In February 2011, a pilot plant "Dream Production" was launched in Leverkusen to produce high-tech plastics using carbon dioxide. This project aims to improve the environment through the use of hazardous industrial waste for production. [17]

$$
\mathrm{E}_{\mathrm{XY}}=\frac{\text { COGS2011-COGS2010 }}{\text { COGS2010 }} \div \frac{\text { Sales } 2010-\text { Sales } 2011}{\text { Sales } 2010}=
$$
$\frac{17975-17103}{17103} \div \frac{35088-36528}{35088}=(-1,24)$.

$E_{X Y}<0$, which indicates the complementarity of this production to the already existing lines of activity of the company. Revenue growth in 2012 was $8.79 \%$, in 2013 $1.05 \%$ and in $2014-5.18 \%$, which indicates a positive trend.

Thus, it can be concluded that the takeovers carried out by Bayer were successful only if the goods complementarity condition was observed. Each of the analyzed transactions confirms the fact of direct dependence of success on the ability of goods to complement each other.

The third company is the Ukrainian company JSC Trust Zhilstroy-1, which is engaged in the construction of residential buildings, the restoration of architectural monuments and the production of building materials.

The company has been operating for 70 years, during which it has implemented 318 projects, and rents out 25 houses a year. It accounts for $65 \%$ of housing in Kharkov [18].

The production structure of JSC "Trest Zhilstroy-1" is shown in Pic. 3.

As it was mentioned earlier, the main activity of the company is the construction of residential buildings. 


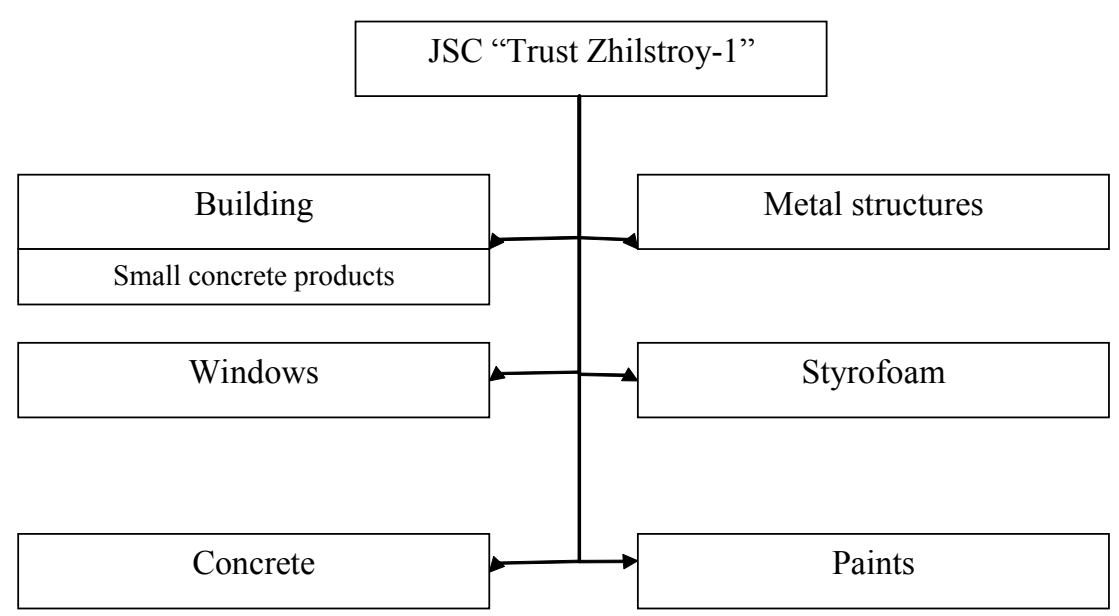

Picture 3. Production structure of JSC "Trust Zhilstroy-1"

However, production is quite diversified, as can be seen in Fig. 3 .

Production of small concrete products (foundation blocks, fencing and finishing elements) was organized in 2013. According to the internal statistics of the company, the calculations of the coefficient of cross elasticity were carried out:

$$
E_{X Y}==\frac{254631-223276}{223276} \div \frac{222576-315764}{222576}=(-0,34) \text {. }
$$

$\mathrm{E}_{\mathrm{XY}}<0$, therefore, small-piece concrete products are complimentary for construction, and the expansion of production in this area will give the company the opportunity to achieve a synergistic effect. In 2014 revenue growth amounted to $1.26 \%$, while in 2015 $42.23 \%$. The positive trend of changes in revenue is due to the resulting synergistic effect. However, we should also mention the fact that in 2013-2014 there was the beginning of a military conflict in Lugansk and Donetsk - areas located close to Kharkov, so the increase in income also occurred due to the influx of refugees in the Kharkov region, which provoked a rise in housing sales economy class.

Also one of the activities of JSC "Trust Zhilstroy-1" is the manufacture of foam used in existing activities, which was started in 2015.

$$
E X Y==\frac{369663-257384}{257384} \div \frac{319753-449212}{319753}=(-1,08) \text {. }
$$

$E_{X Y}<0$, which indicates the complementarity of the foam to the already existing types of production. The increase in revenue in 2016 relative to 2015 amounted to $14.09 \%$, which indicates the occurrence of a synergistic effect.

That is, both implemented diversifications were aimed at the production of goods that were complementary to existing ones, and both led to a synergistic effect.

\section{CONCLUSIONS}

So, it can be concluded that when deciding whether to carry out diversification in one area or another, new to the enterprise, it is necessary to determine the complementarity of the new product to the existing one. The production of complimentary goods strengthens the enterprise in the market because it makes it possible to achieve a synergistic effect, which, in turn, makes the company more resistant to various negative exogenous factors.

Using the example of three companies operating in different areas, the effect and expediency of using a modified coefficient of demand elasticity, which is the main indicator of the complementarity of goods, was clearly demonstrated.

Also, using the example of Bayer AG revenue analysis during the global financial crisis of 2000 , it was proved that diversified synergistic firms are more resistant to crises, as they have the ability to minimize their losses.

It should be noted that the coefficient of crosselasticity takes into account only a few objective factors affecting the state of the company. However, there are many other factors that determine the efficiency of a firm, such as financial and political crises, military conflicts, management style of a company in managing a firm, etc.

\section{Література:}

1. Ігор Ансофрф Стратегическое управление Пер. с англ. - М.: Издательство "Aldebaran", 1989. - 303 с.

2. Котлер Ф. Основы маркетинга Краткий курс Пер. с англ. - М.: Издательский дом "Вильяме", 2007. - 656 с.

3. Томпсон А., Стрикленд А. Стратегичний менеджмент. - 12-е издание: Пер. с англ. - М.: Издательский дом "Вильяме", 2006. - 928 с.: ил. - Парал. тит. англ.

4. Богуславський Є. І., Шибалкіна Ю. С. Дослідження ефректу мультиплікатора на рівні економіки підприємства / Є.І. Богуславський, Ю.С. Шибалкіна / / Економіка розвитку. - Х.: Вид-во ХНЕУ, 2008. - С. 70-73.

5. Терещенко О.О. Фінансова діяльність суб'єктів господарювання: Навч. посібник. - К.: КНЕУ, 2003. $554 \mathrm{c}$.

6. Оценка стоимости методом дисконтирования денежных потоков [Електронний ресурс]. -Режим доступу: http://mit.su/valuation /examples/16-gazp-dcfvaluation.html

7. DCF теорія [Електронний ресурс]. - Режим доступу: http://www.invest-liga.ru/articles/dcf-teorija

8. Boguslavkiy Y.I., Diversification: the synergetic effect or the multiplier of complementary? / Y.I. Boguslavkiy, A.l. Tishchenko / / Науковий журнал "Економіка розвитку". - 2012. - № 2. - С. 50-57. 
9. Перекрестная эластичность спроса по цене [Електронний ресурс]. - Режим доступу: http://microeconomica.economicus.ru/index1.php?file=4-3

10. Nestle S.A. [Електронний ресурс]. - Режим доступу: https://www.nestle.com

11. Nestle S.A. Our businesses [Електронний ресурс]. - Режим доступу: https://www.nestle.com/aboutus / overview/businesses

12. Nestle S.A. Creating Shared Value [Електронний ресурс]. - Режим доступу: https://www.nestle.com/ aboutus/history/nestle-company-history\#tab-2006

13. Nestle S.A. Documents and reports [Електронний ресурс]. - Режим доступу: https://www.nestle.com/ aboutus/mediadocuments\#

14. Bayer AG [Електронний ресурс]. - Режим доступу: https://www.bayer.com

15. Bayer AG Names, Facts, Figures about Bayer [Електронний ресурс]. - Режим доступу: https:// www.bayer.com/en/profile-and-organization.aspx

16. Bayer AG Reorganization of the Group [Електронний ресурс]. - Режим доступу: https://www.bayer.com/en/2001-2010.aspx

17. Bayer AG Investing in the Future [Електронний ресурс]. - Режим доступу: https://www.bayer.com/ en /2010-2018.aspx

18. АО "Трест Жилстрой-1" История [Електронний ресурс]. - Режим доступу: http://gs1.com.ua/page/ history

\section{References:}

1. Ansoff, I. (1989), Strategicheskoe upravlenie [Strategic menegement], Aldebaran, Moscow, Russia.

2. Kotler, F. (2007), Osnovy marketinga Kratkii kurs [Marketing bases Short course], Willame, Moscow, Russia.

3. Thompson, A. and Striklend, A. (2006), Strategicheskii menedzhment [Strategic management], Willame, Moscow, Russia.

4. Boguslavskiy, E. I. and Shybalkina, Yu. S. (2008), "The investigation of the multiplier on the level of economy of the enterprise", Ekonomika rozvytku, vol. 34, no. 2, pp. $70-73$.

5. Tereshchenko, O. O. (2003), Finansova diyal'nist' sub'yektiv hospodaryuvannya [The financial activities of entities], KNEU, Kyiv, Ukraine

6. Mit.su (2015), "Valuation by discounted cash flows" available at: http://mit.su/valuation/examples/16gazp-dcf-valuation.html. (Accessed 4 March 2019).

7. Invest-Liga (2016), "DCF theory" available at: http:/ /www.invest-liga.ru/articles/dcf-teorija. (Accessed 16 March 2019).

8. Bohuslavskiy, Ye. I. and Tyshchenko, A. I. (2012), "Diversification: synergetic effect, or the multiplier of complementarity?", Ekonomika rozvytku, vol. 62, no. 2, pp. $50-57$.

9. Economicus (2007), "Cross-elasticity of demand at price", available at: http://microeconomica.economicus.ru/index1.php?file=4-3 (Accessed 16 March 2019).

10. Nestle S.A. (2019), "About company" available at: https://www.nestle.com (Accessed 8 April 2019).

11. Nestle S.A. (2019), "Our businesses" available at: https: / / www.nestle.com / aboutus /overview/businesses (Accessed 8 April 2019).
12. Nestle S.A. (2019), "Creating Shared Value" available at: https://www.nestle.com/aboutus/history/ nestle-company-history\#tab-2006 (Accessed 8 April 2019).

13. Nestle S.A. (2019), "Documents and reports" available at: https://www.nestle.com/aboutus / mediadocuments \# (Accessed 8 April 2019).

14.eBayer AG (2019), "Our company" available at: https://www.bayer.com (Accessed 11 April 2019).

15.eBayer AG (2019), "Names, Facts, Figures about Bayer" available at: https://www.bayer.com/en/profileand-organization.aspx (Accessed 11 April 2019).

16. Bayer AG (2010), "Reorganization of the Group" available at: https://www.bayer.com/en/20012010.aspx (Accessed 11 April 2019).

17. Bayer AG (2019), "Investing in the Future" available at: https://www.bayer.com/en/2010-2018.aspx (Accessed 11 April 2019).

18. Zhylstroi-1 (2009), "History trust Zhylstroi-1", available at: http://gs1.com.ua/istoriya / (Accessed 15 April 2019).

Стаття надійшла до редакиіӥ 28.05.2019 p.

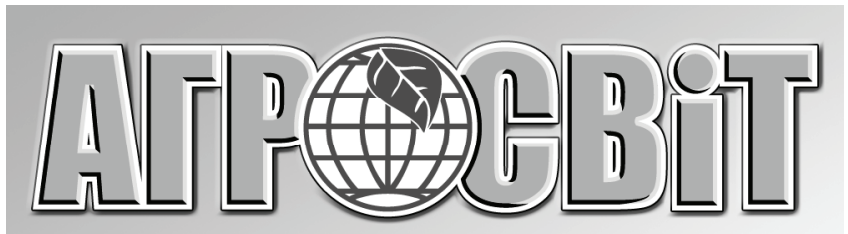

www. agrosvit. info

Передплатний індекс: 23847

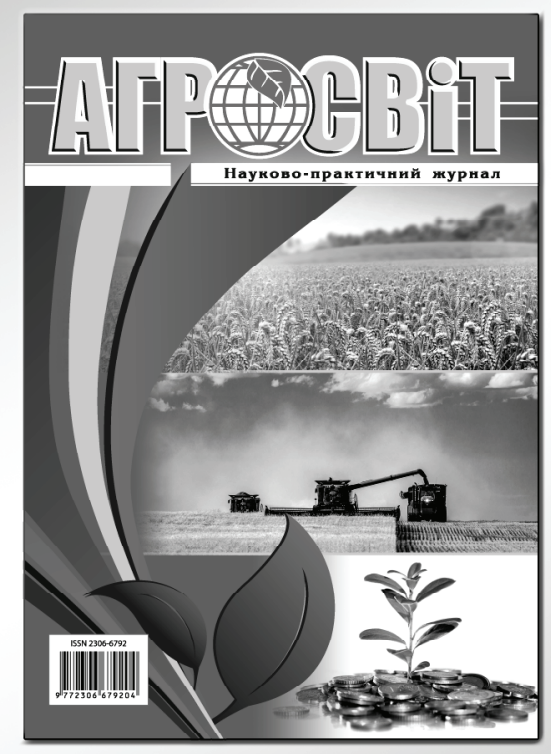

Виходить 24 рази на рік

Видання включено до переліку

наукових фахових видань України 3 ЕКОНОМІКИ 